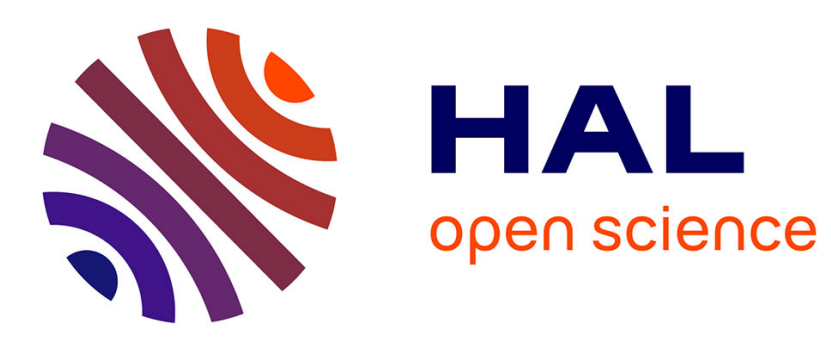

\title{
Ultrastructure of trout spermatozoa: Changes after dilution and deep-freezing
}

Roland Billard

\section{To cite this version:}

Roland Billard. Ultrastructure of trout spermatozoa: Changes after dilution and deep-freezing. Cell and Tissue Research, 1983, 228, pp.205-218. 10.1007/BF00204873 . hal-01600629

\section{HAL Id: hal-01600629 \\ https://hal.science/hal-01600629}

Submitted on 2 Jun 2020

HAL is a multi-disciplinary open access archive for the deposit and dissemination of scientific research documents, whether they are published or not. The documents may come from teaching and research institutions in France or abroad, or from public or private research centers.
L'archive ouverte pluridisciplinaire HAL, est destinée au dépôt et à la diffusion de documents scientifiques de niveau recherche, publiés ou non, émanant des établissements d'enseignement et de recherche français ou étrangers, des laboratoires publics ou privés.

\section{다(1)(2)}

Distributed under a Creative Commons Attribution - ShareAlikel 4.0 International 


\title{
Ultrastructure of trout spermatozoa: Changes after dilution and deep-freezing
}

\author{
Roland Billard \\ Laboratoire de Physiologie des Poissons, I.N.R.A., Jouy en Josas, France
}

\begin{abstract}
Summary. Trout spermatozoa taken from the testis, vas deferens and ejaculate are described at the ultrastructural level. The morphology of the spermatozoa head, changes in the middle-piece structure, and the relationship between the centrioles and the flagellum were studied under consideration of their role in the reproduction of this species. Morphological changes observed after dilution of the spermatozoa in freshwater or saline and subsequent freezing deserve attention in connection with certain manipulations used in fish farms and laboratories.
\end{abstract}

Key words: Spermatozoa - Ultrastructure - Deep-freezing - Sperm manipulation - Trout

In spite of many studies on the morphology of fish spermatozoa (Mattei 1969a, b; Billard 1970, 1973; Mattéi and Mattéi 1976,1978a, b; Afzelius 1978), there has been little work concerned with their ultrastructure. A few electron-microscopic studies have been carried out using metalization (Rotheli et al. 1950; Fischer et al. 1952; Hug et al. 1953; Ginsburg 1963), and brief descriptions using transmission electron microscopy have been published (Furieri 1962; Nicander 1968). Similar to most teleost spermatozoa, the structure of trout spermatozoa is simple; the sperm head has no acrosome, and a deep nuclear notch at its base contains the centrioles. The very simplified middle piece is reduced to a mitochondrial ring; the flagellum, 25 to $35 \mu \mathrm{m}$ in length, is extremely narrow at its tip, consisting of only one or two fibrils (Furieri 1962).

The present paper reports a more detailed study of the structure of sperm head and the middle piece of trout (Salmo trutta fario and Salmo gairdneri) spermatozoa, as well as the relation between the two centrioles and the flagellum. In order to appreciate the effects of some sperm manipulations used in fish farms or in laboratories, ultrastructural changes were also described after sperm dilution and freezing.

Send offprint requests to: R. Billard, I.N.R.A., Hydrobiologie, F78350, Jouy-en-Josas, France. Present adress: I.N.R.A. Laboratoire de Physiologie des Poissons Campus de Beaulieu, 35042 Rennes Cedex, France 


\section{Materials and methods}

The testis, vas deferens and sperm of two species of trout (Salmo trutta fario and Salmo gairdneri) were studied. Males from a commercial fish-farm were brought to the laboratory between September and December, i.e., before and after the onset of spermiation. On arrival, they were anesthetized with MS 222, and fragments of tissue were sampled. After fixation for $30 \mathrm{~min}$ in $4 \%$ glutaraldehyde solution in a phosphate buffer at $\mathrm{pH} 7.25$, the fragments were postfixed for $1 \mathrm{~h}$ in a $2 \%$ solution of osmic acid with the same buffer. After embedding in Epon, the specimens were stained with uranyl acetate and lead citrate and covered with a carbon film for observation in a Siemens Elmiskop I electron microscope. The terminologies of Afzelius (1959) and Gibbons and Grimstone (1960) were used to describe the flagella and that of André (1962) to describe the middle piece.

For the dilution experiments, the spermatozoa of the rainbow trout were diluted at a rate of $1 / 1000$ in distilled water or in saline solution used as an insernination diluent ( $250 \mathrm{mOsm}, \mathrm{pH} 9,0.02 \mathrm{M}$ TRISbuffer, 0.05 M glycine; Billard 1977). Both the diluted and the undiluted control spermatozoa were fixed $30 \mathrm{~s}$ and $5 \mathrm{~min}$ after dilution with the same glutaraldehyde solution as described above and centrifuged $(1800 \mathrm{~g})$ at $4^{\circ} \mathrm{C}$ for $10 \mathrm{~min}$. The pellet was then postfixed and treated like the testicular fragments. The deep-freeze technique of Billard (1978a), Legendre and Billard (1980) and Billard (unpublished) was used, i.e., dilution in a saline solution with the addition of $20 \%$ egg yolk and then of $10 \% \mathrm{DMSO}$. The sperm were diluted in this solution $(1 / 3, v / v)$ and then deep-frozen without equilibration time either by direct immersion of straw in liquid nitrogen or gradually either in the vapor (deep-freezing rate: $20-30^{\circ} \mathrm{C}$ per min) or in dry-ice in the form of $100-\mu$ pellets. After thawing, the spermatozoa were fixed and centrifuged similar to the fresh sperm.

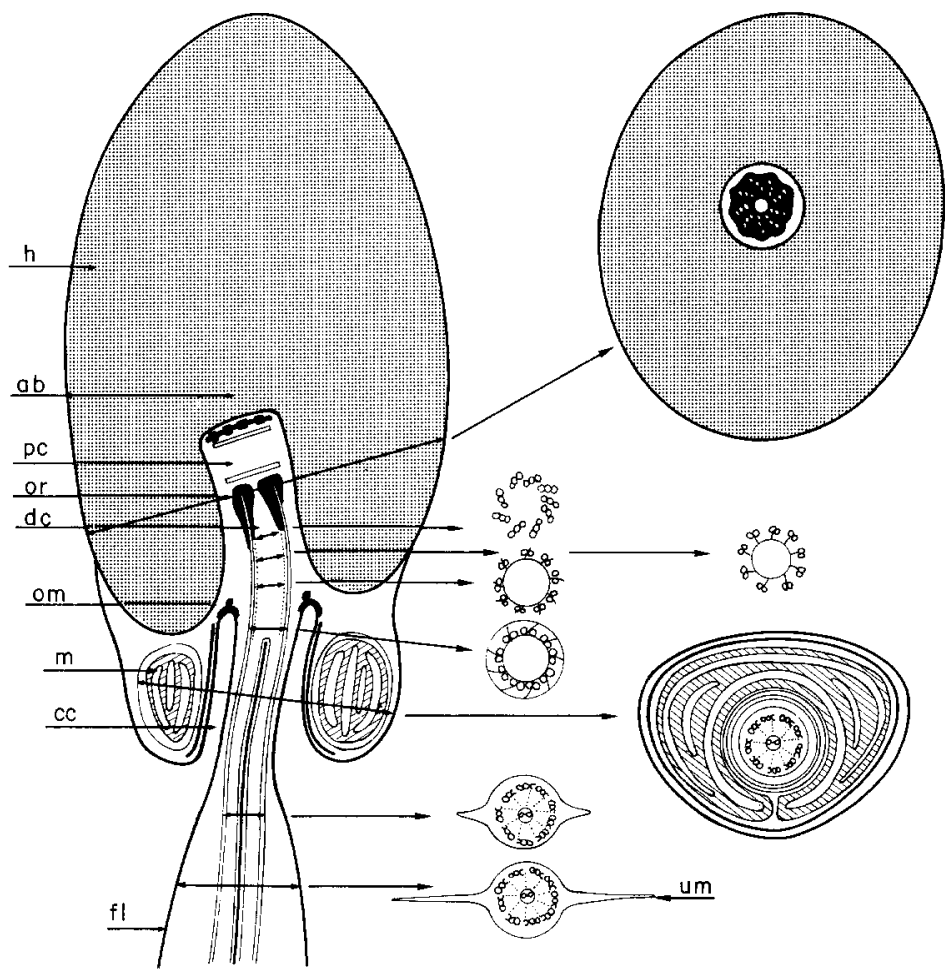

Fig. 1. Schematic representation of trout spermatozoa; $a b$ anterior bar; $c c$ cytoplasmic canal; $d c$ distal centriole; $f l$ flagellum; $h$ head; $m$ mitochondria; or osmiophilic ring; $o m$ osmiophilic mass; $p c$ proximal centriole; $u m$ undulating membrane 

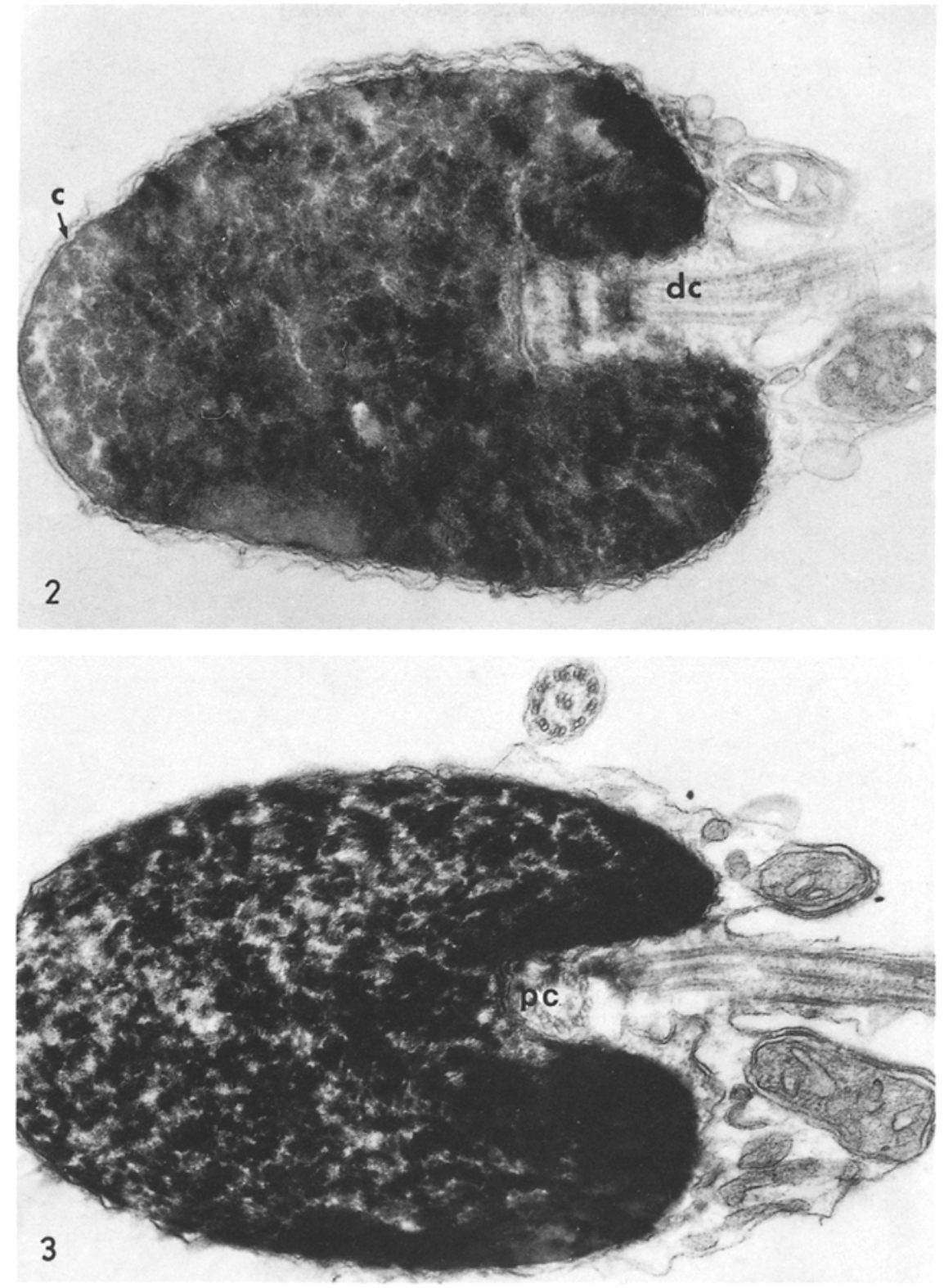

Figs. 2 and 3. Spermatozoa in the spermduct of a spermiating adult male trout

Fig. 2. Longitudinal section through a sperm head passing through a plane parallel to the proximal centriole. Note the condensed chromatin (c) lying against the nuclear membrane at the top of the head; $d c$ distal centriole. $\times 40000$

Fig. 3. Longitudinal section perpendicular to the section in Fig. 2. Illustration of relationships between the two centrioles. The highly osmiophilic transverse axes are closely apposed to the proximal centriole; $p c$ proximal centriole. $\times 42000$ 

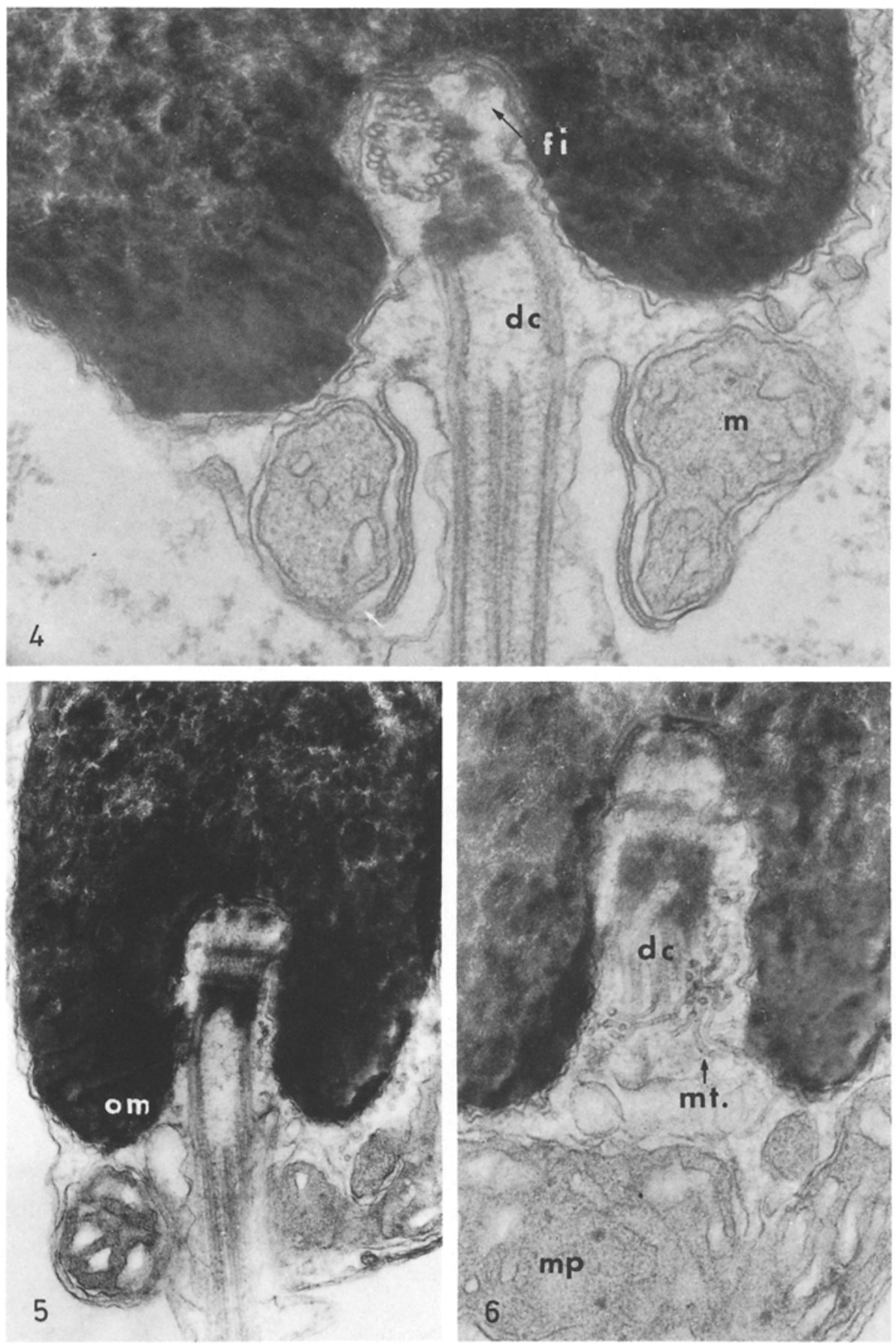

Fig. 4. Trout spermatozoon in the lobular lumen in September ( 2 months before onset of spermiation). Some filaments $(f i)$ connect the two centrioles to their system of attachment. The mitochondrial body $(m)$ is not completely condensed; $d c$ distal centriole. $\times 60000$

Fig. 5. Spermatozoon recovered during the reproductive period. The medial transverse bar is attached to the sperm head. The differentiation of the mitochondrial body is completed. At the bottom of the invagination of the plasma membrane an osmiophilic mass is seen above the membrane thickening $(\mathrm{om})$. $\times 37000$

Fig. 6. Same as Fig. 4. Microtubules $(m t)$ surround the distal centriole $(d c) ; m p$ middle piece. $\times 60000$ 

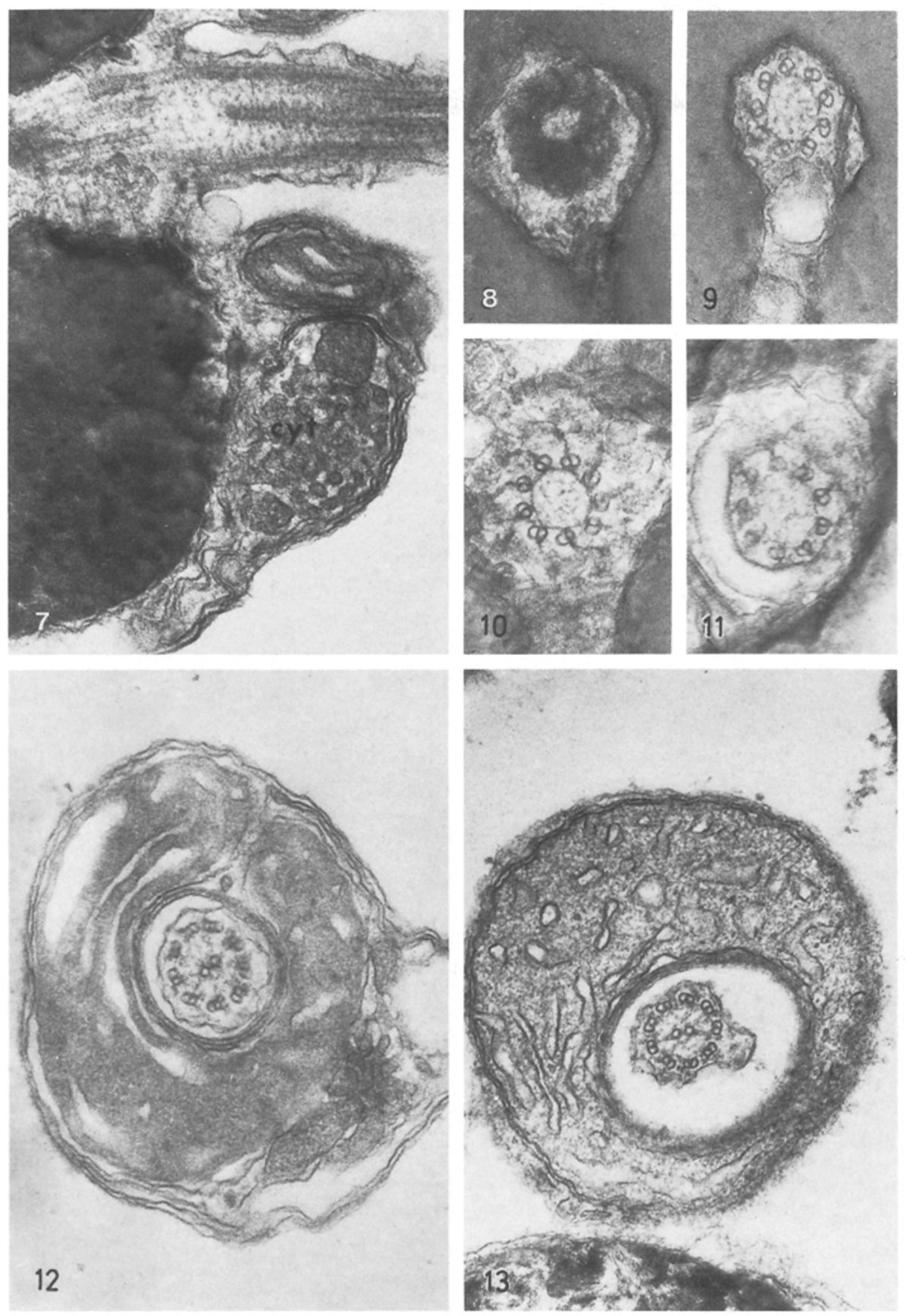

Fig. 7. Spermiating male. Large amount of cytoplasm (cy) adjacent to the mitochondrial ring $\times 60000$

Fig. 8. Transverse section of a distal centriole at the level of the osmiophilic ring. $\times 60000$

Fig. 9. Transverse section of the flagellum immediately below the distal centriole. $\times 57000$

Fig. 10. Transverse section of the flagellum at the base of the sperm head. $\times 60000$

Fig. 11. Trans verse section of the flagell um at the bottom of the invagination of the plasma membrane. $\times 60000$

Fig. 12. Male in spermiation. Transverse section of the middle piece showing the incompletely closed mitochondrial ring. $\times 50000$

Fig. 13. Same as Fig. 12 but 1 month before the onser of sperniation. The mitochondrial body nor completely differentiated. $\times 45000$ 


\section{Results}

Since the structures in the two species studied were identical, the spermatozoa of the rainbow trout will be used to illustrate the common ultrastructure of these cellular elements.

Sperm head. The general morphology of the sperm head is summarized in Figs. 1-3. The head is ovoid-shaped, measuring about $2.5 \mu \mathrm{m}$ in its longest axis and 1.5 to $2 \mu \mathrm{m}$ in diameter. The aspect of the chromatin varies, being sometimes compact and homogeneous but usually granular with electron-lucent patches (Figs. 2, 3). The posterior part of the nuclear and the plasma membranes is folded. No trace of an acrosome is found; the darker edge of the top of the head (Fig. 2) corresponds to nuclear material adhering closely to the nuclear envelope the two layers of which merged at that level. In the other areas, the inner layer was often closely apposed to the nuclear material but is occasionally detached (Fig. 4); an outer layer is present. A cytoplasmic membrane covering the head sometimes retains cytoplasmic residues.

Centriolar complex. The two centrioles, which are about the same size (length: $30 \mathrm{~nm}$; diameter: $22 \mathrm{~nm}$ ) are arranged at a right angle to the base of the head, in a roughly cubical depression equivalent to an implantation groove. The distal centriole is slightly displaced in relation to the proximal centriole, so that the two centriolar axes are not in the same plane (Fig. 3). The extent of this displacement varies from one spermatozoon to another. The anterior part of the distal centriole, embedded in an electron-dense material (Figs.2-6, 8) is attached by several filamentous bundles to a series of highly osmiophilic axes, arranged parallel to the proximal centriole (Figs. 2-4, 6). Some images indicated that these osmiophilic filaments are attached to the triplets of the proximal centriole (Fig. 4). The transverse sections of this centriole (Fig. 3,4), which is bounded by the wall of the implantation groove, the filamentous system and the distal centriole, show it to be slightly ovoid $(16 \times 25 \mathrm{~nm})$. Between the distal centriole and the lateral walls of the implantation groove, very twisted microtubular structures (outer diameter: about $14 \mathrm{~nm}$ ) are observed (Fig. 6).

Fig. 14. Transverse section of a flagellum at the level of the origin of the central fibers. $\times 60000$

Fig. 15. Transverse section of a flagellum at the level where the two cytoplasmic extensions appear. Their axes pass through the plane of the central doublet. $\times 60000$

Fig. 16. Opposite symmetrical cytoplasmic extensions. Their axes are perpendicular to the plane of the central doublet. $\times 60000$

Fig. 17. Vesicles visible in the cytoplasmic extensions. $\times 60000$

Fig. 18. Three cytoplasmic extensions. $\times 60000$

Fig. 19. Asymmetrical cytoplasmic extensions. Their axes are oblique to the plane of the two central fibers. $\times 60000$

Fig. 20. Numerous vesicles dilate the cytoplasmic sheath of the flagellum. $\times 52000$ 

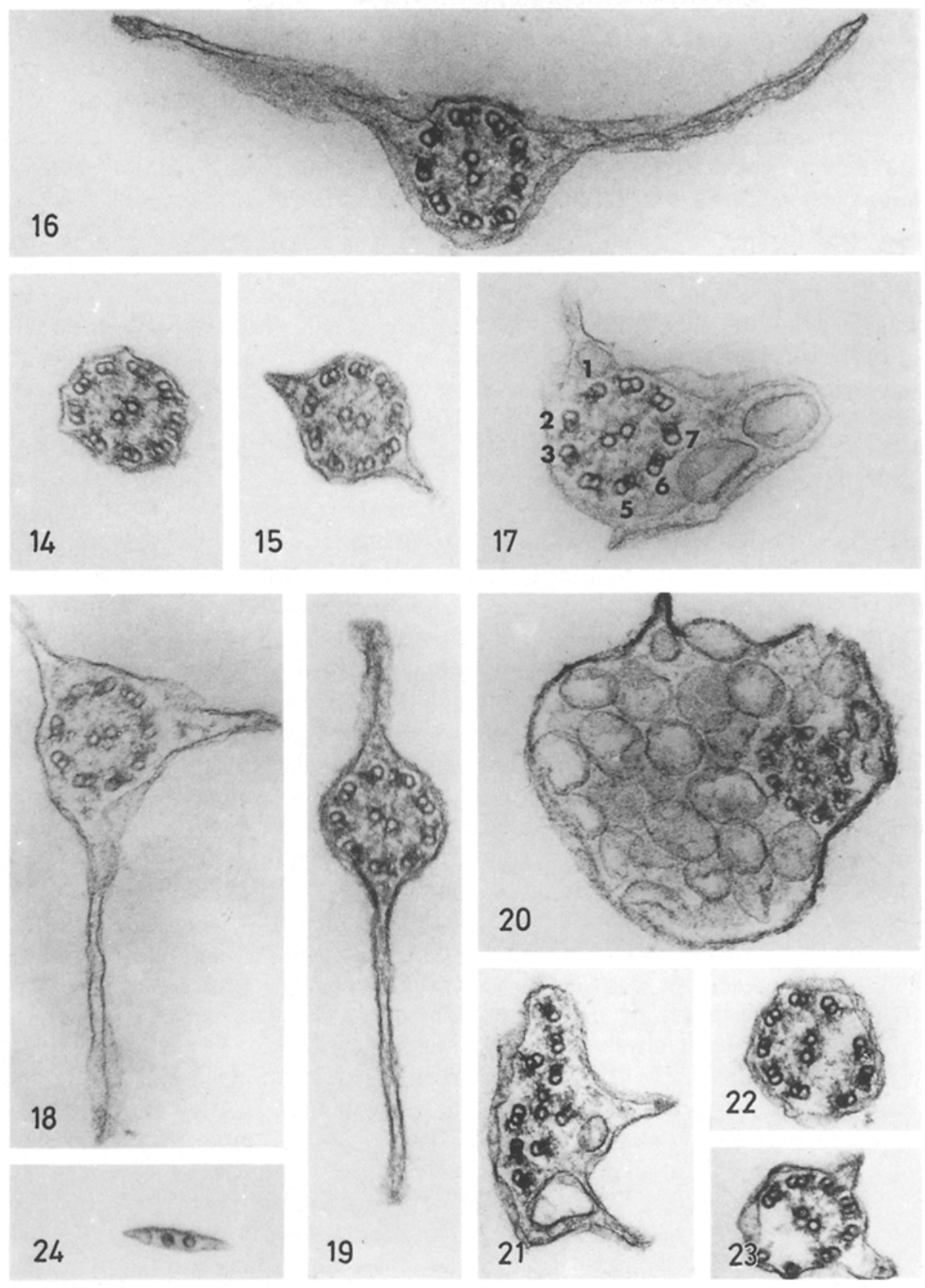

Figs. 21, 22. Change in microtubule arrangement. $\times 60000$

Fig. 23. Loss of B-tubule and of corresponding A-tubule arms, while traces of the cytoplasmic extensions are still visible. $\times 60000$

Fig. 24. Only two fibrils remain at the very flat tip. $\times 60000$ 
Middle piece. Several mitochondria are sometimes identified in the middle piece, but they are usually fused together, and the mitochondrial body or resulting chondriosome is shaped like an incompletely closed ring (Fig. 12). This chondriosome is bounded by an outer and an inner membrane; the intermembranous space is dilated at the level of the cristae (Figs. 4, 13) to form the pseudomatrix; mature spermatozoa possess a dense region (Figs. 5, 12) corresponding to the spermatozoa found in lobules after the onset of spermiation.

The middle piece is irregularly shaped; the asymmetry shown in Figs. 2 and 13 is not general (Fig. 12). Cytoplasmic structures are sometimes present in the middle piece (Fig. 7). The middle piece is completely separated from the flagellum by an invagination of the cell membrane, which reaches from the head to the base. At the bottom of this fold, the plasma membrane, surmounted by an osmiophilic mass, is more dense (Figs. 4, 5). A second membrane is observed all along the middle piece between the invaginated membrane of the cell and the outer layer of the chondriosomic membrane. Thus, triple concentric structures are visible (Figs. 4, 5, 12, 13).

Flagellum. The outermost microtubules of each of the triplets of the distal centriole disappear, and the two innermost microtubules, remaining at the flagellum, elongate to form nine peripheral doublets, connected to each other by an inner ring (Fig. 9). At the base of the implantation groove, nine outer arms are seen extending from between the two subtubules of each pair (Fig. 10) at a level that appears to be in front of the previously mentioned osmiophilic mass. These arms are attached to the flagellar membrane (Fig. 11), but disappear when the pair of the central tubules becomes visible in the sections (Fig. 12). The plane of this pair of central tubules passes through the plane of the longitudinal axis of the proximal centriole. The two central tubules are connected to each other by a straight line and by two lines each forming a half-circle and thus constituting a sheath. From this central sheath extend nine arms, which are attached to the A tubules closest to the center and all having two arms. This structure is found over the entire length of the flagellum, although its arrangement was sometimes disrupted (Figs. 21, 22). The B tubules at the distal end of the flagellum disappear first; at the same time the corresponding A tubules lose their arms (Fig. 23). At the tip, only one or two tubules remain (Fig. 24).

The cytoplasmic membrane, which surrounds the flagellum, first remains closely apposed to the axoneme (Fig. 14); then two lateral extensions appear at about $1 \mu \mathrm{m}$ behind the middle piece (Figs. 15, 16). When counted on 200 transverse sections of flagella, two opposite lateral extensions $(82 \%)$, and more rarely perpendicular ones $(6.4 \%)$, are found. Sometimes $(12 \%)$ there are three extensions (Fig. 18) which are not always clearly defined due to the presence of vesicles (Figs. 17, 20, 21). The two cytoplasmic extensions on the same flagellum are not always equal (Fig. 19), and their orientation in relation to the central doublet varies. In mature spermatozoa, the axis of the cytoplasmic extensions is in the plane of the central doublet $(38 \%)$ perpendicular to that plane $(16 \%)$, or oriented differently than in the two preceding cases $(46 \%$ ). The A tubule of the 1, 2, 3, 5, 6, 7 doublets (see Fig. 17) appears darker with an intratubular septum especially when the lateral extentions are present.

Ultrastructural changes after dilution and deep-freezing. Spermatozoa were considerably altered when immersed in distilled water. After an exposure of $30 \mathrm{~s}$, the 

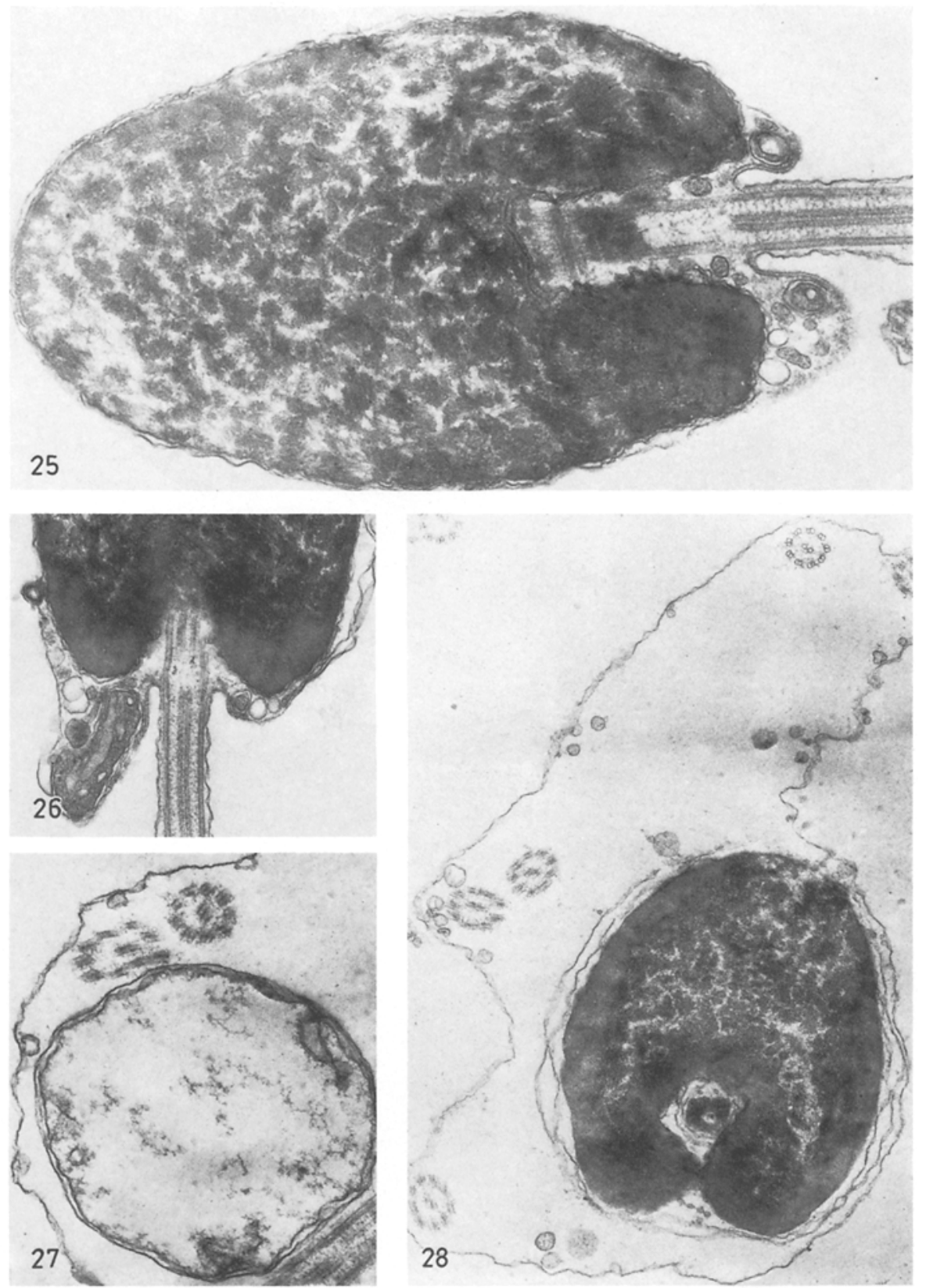

Figs. 25-28. Morphology of spermatozoa diluted in freshwater (1/1000 dilution); for water composition, see Billard 1978

Figs. 25, 26. Sperm head after $30 \mathrm{~s}$ in freshwater. The middle piece is greatly reduced and often displaced to one side (Fig. 26) Fig. 25: $\times 31$ 450; Fig. 26: $\times 25500$

Fig. 27. After $5 \mathrm{~min}$ in freshwater the middle piece is very swollen. $\times 35700$

Fig. 28. Same condition as in Fig. 27. The plasma membrane is loosened from the sperm head. $\times 25500$ 

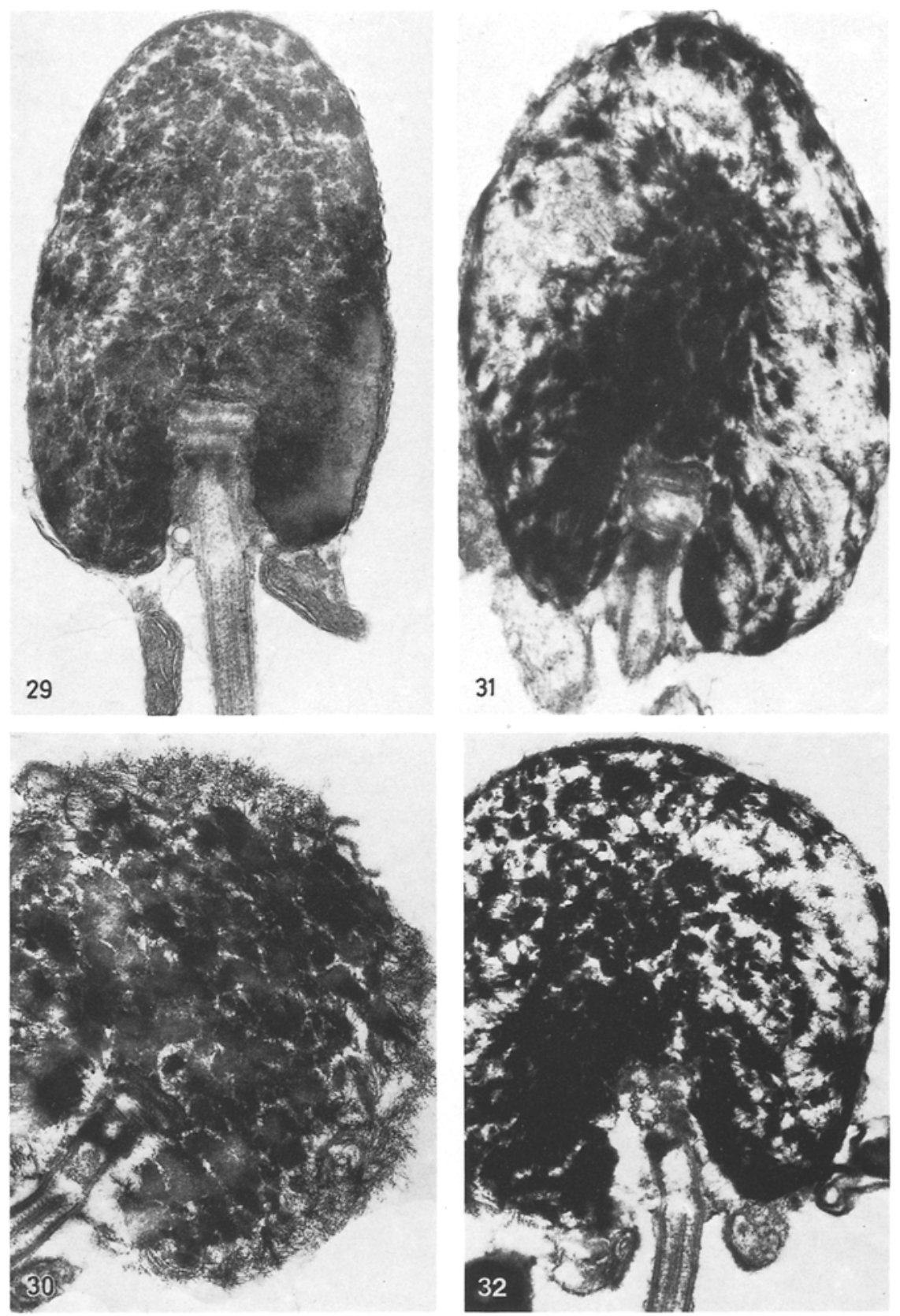

Fig. 29. Spermatozoon after $5 \mathrm{~min}$ in insemination diluent $(1 / 100$ dilution). $\times 24000$

Fig. 30. Spermatozoon diluted in a deep-freezing diluent (medium of Ott and Horton 1971) with $10 \%$ DMSO added, then immersed directly in liquid nitrogen. $\times 27200$

Fig. 31. Spermatozoon diluted in the same medium as in Fig. 30 and deep-frozen in liquid nitrogen vapor (deep-freezing rate; $20-30^{\circ} \mathrm{C} / \mathrm{min}$ ). $\times 27200$

Fig. 32. Same dilution conditions as Fig. 30, then deep-freezing on dry-ice. $\times 26400$ 
middle piece was greatly reduced (Fig. 25) and sometimes displaced laterally (Fig. 26). After 5-min dilution, there were even greater alterations: the plasma membrane separating the sperm head from the flagellum displayed signs of swelling (Fig. 28). The middle piece also appeared to be enlarged (Fig. 27). After the sperm had been mixed with the insemination diluent, the ultrastructural changes were less marked; at the end of $5 \mathrm{~min}$, the middle piece flattened and extended distally (Fig. 29). After deep-freezing of the spermatozoa, extensive modifications were seen. When the spermatozoa were diluted with deep-freeze medium and immersed directly in liquid nitrogen, the plasma membrane as well as the middle piece disappeared entirely (Fig. 30). In contrast, when the spermatozoa were deep-frozen gradually in liquid nitrogen vapor (deep-freezing at $20-30^{\circ} \mathrm{C} / \mathrm{min}$, see Fig. 31 , or on dry ice, see Fig. 32), the membranous structures were not so greatly altered but the aspect of chromatin structures was considerably modified. Such modifications were observed in most of the spermatozoa examined (approximately 100).

\section{Discussion}

Sperm head. As reported by Furieri (1962), the head of trout sperm has no structure that can be identified as an acrosome. However, the edge of the chromatin, condensed against the inner layer of the nuclear membrane (Fig. 2) and formed during spermiogenesis (Billard, unpublished results), is found in other species in association with acrosome formation (Lepadogaster: Mattéi and Mattéi 1978b; lizard: Clark 1967; Horstmann 1961).

In some spermatozoa, the remains of the cytoplasm around the head and near the middle piece suggest a state of "immaturity". Other structures around the distal centriole (Fig. 6) might also be cytoplasmic residues, but should probably be interpreted as microtubules which, due to their twisted morphology and size $(14 \mathrm{~nm})$, differ from the microtubules constituting the flagellar fibers (diameter: $25 \mathrm{~nm})$.

Centrioles. A scheme of the relationships between the two centrioles has been proposed previously (Billard 1970). The distal centriole attached to the transverse axis system includes a free portion resting on the proximal centriole, which varies in form between a circle and an elipse on some images, and may act as a "spring".

Middle piece. As in other teleosts, i.e., Poecilia reticulata, (Lebistes reticulatus Porte and Follénius 1960; Mattéi and Boisson 1966), the middle piece is completely separated from the flagellum by the invagination of the cell membrane (Nicander 1968). The membrane, with the outer coat of the mitochondrial body and the invaginated cellular membrane, constitutes a triple osmiophilic structure (Fig. 12), which is organized during spermiogenesis (Billard, unpublished results). Elfvin (1968) described an analogous but reverse differentiation between the outer and inner mitochondrial membranes of the rat spermatozoon. Spermatozoa of Testacella possess an additional dark layer on the outer as well as in the inner side of the mitochondrial body (André 1962). 
When the middle piece appears to be asymmetric, it is never oriented in the same plane of symmetry as the flagellum (identified by the pair of central fibers), as has been observed in many species (see Andre 1962).

Structural changes in the mitochondrial body occur after spermiogenesis has been achieved; the dilatation of the cristae and the appearance of the pseudomatrix are hardly visible in spermatozoa (see Figs. 4,12 ), which can be considered as true spermatozoa (and not spermatids), because their cytoplasm has totally disappeared and they are located in the lumen of the lobule (and not in cysts). The intermembranous spaces tend to be grouped in the form of concentric cristae, while the matrix becomes dense; final differentiation does not greatly modify the basic mitochondrial structure, and the middle piece of trout spermatozoa may be classified as belonging to group II according to André (1962) or to IIB according to Idelman (1967). Final structural modifications might be related to physiological changes, such as modifications in the ability of potassium to inhibit motility occurring in the spermatozoa at the end of spermiogenesis and spermiation (Billard, unpublished results).

Flagellum. The flagellum, of a $9+2$ structure, has a total length of about $35 \mu \mathrm{m}$ and a $30 \mu \mathrm{m}$-long membrane composed of two opposite, lateral cytoplasmic extensions, which are usually symmetrical. In the mature testicular spermatozoon, this membrane is not oriented uniformly to the plane of symmetry of the axoneme, while during spermiogenesis the site of these extensions passes through the plane of the central doublet (Billard 1969). In contrast to the data of Rotheli et al. (1950), no contractile structure was found in the cytoplasmic extensions, thus confirming the results of Hug et al. (1953). The lateral extensions are comparable to the undulating membrane described in amphibians by Burgos and Fawcett (1956).

The decrease in diameter at the tip of the flagellum is a result of (1) lack of cytoplasmic extension, and (2) loss of tubules. The arms disappear when the peripheral doublet dissociates, as shown by Nicander and Bane (1962) in the boar. The same process has been observed in the guppy (Mattei et al. 1967), and Satir (1965) reported analogous morphological changes in the ciliary tips. Moreover, the flagellum of the salmonid spermatozoon shows an intratubular septum in the Amicrotubules of doublets 1, 2, 3, 4,6 and 7 (cf. Mattéi et al. 1981). This partitioning septum, which coincides here with the presence of the lateral extensions of the flagellar membrane, also occurs in other families (Mattéi et al. 1979).

Morphological changes. Following dilution and deep-freezing, structural changes due to various types of treatments have been reported previously (Billard and Breton 1970; Billard 1978b). The spermatozoon is very sensitive to changes in osmotic pressure and to deep-freezing, the plasma membrane swelling and rupturing after dilution in distilled water. Ultrastructural changes observed following dilution in distilled water are similar to those described after dilution in freshwater (Billard 1978 b). On the contrary, except for flagellar coiling, there are no marked modifications in the morphology of spermatozoa when the sperm are diluted in a physiological medium (Fig. 33). However, even under these conditions, motility is short-lived not exceeding several minutes. Attemps to initiate motility (e.g., addition of ATP or cyclic AMP) after a first dilution are usually unsuccessful. 
Only the addition of theophylline to the dilution medium, probably causing an increase in endogenous cyclic AMP, initiates motility of spermatozoa, however, at a somewhat lower level (Billard 1980; Benau and Terner 1980). It is possible that the structural changes observed in the flagellum are not reversible and limit the amplitude of the movements. The considerable ultrastructural alterations, particularly those visible in chromatin structure after the spermatozoa were thawed, are intriguing especially in connection with the development of a technique for deep-freezing trout spermatozoa. In fact, changes in chromatin could prevent fertilization or alter embryonic development. With the present deep-freezing technique (Legendre and Billard 1980), the spermatozoa show lower motility after thawing, but the fertilization rate is similar to that in controls (fresh sperm), provided the total number of spermatozoa is increased and no marked abnormalities in the embryos are observed after fertilization with deep-frozen sperm. In spite of this, however, the integrity of the chromosomes and the state of the animals should be checked at a more advanced stage of development, considering the alterations of the chromatin. However, the possibility remains open to discussion that the spermatozoa which participated in fertilization were not damaged. As already mentioned, a larger number of spermatozoa is required for fertilization when sperm is frozen (Legendre and Billard 1980). Fertilization may then depend on an increasing number of non-damaged spermatozoa present in the frozen sperm; however, in order to estimate their percentage and to test this hypothesis, more extensive studies involving larger numbers of spermatozoa are necessary.

Acknowledgements. The author wishs to thank Ms. Alice Daifuku for editing the English text.

\section{References}

Afzelius BA (1959) Electron microscopy of the sperm tail. J Biophys Biochem Cytol 5:269-279

Afzelius BA (1978) Fine structure of the gardfish spermatozoon. J Ultrastruct Res 64:309-314

André J (1962) Contribution à la connaissance du chondriome. J Ultrastruct Res Supp 3:1-185

Benau D, Terner C (1980) Initiation, prolongation and reactivation of salmonid spermatozoa. Gametes Research 3:247-257

Billard R (1969) Ultrastructure comparée de spermatozoïdes de quelques poissons téléostéens. Baccetti Ed. Quaderno 137:71-79

Billard R (1970) La spermatogenèse de Poecilia reticulata. IV - La spermiogenèse. Etude ultrastructurale. Ann Biol Anim Bioch Biophys 10:493-510

Billard R (1973) La spermatogenèse des poissons poecilidae; quelques comparaisons avec celle d'autres espèces de poissons. Bull Fr Pisc 250:17-34

Billard R (1977) Utilisation d'un système TRIS-Glycocolle pour tamponner le dilueur d'insémination de Truite. Bull Fr Pisc 264:102-112

Billard R (1978a) Some data on gametes preservation and artificial insemination in teleost. Actes de colloques du CNEXO 8:59-73

Billard R (1978b) Changes in structure and fertilizing ability of marine and freshwater fish spermatozoa diluted in media of various salinities. Aquaculture 14:187-198

Billard R (1980) Prolongation de la durée de motilité et du pouvoir fécondant des spermatozoïdes de truite Arc-en-ciel par addition de théophylline au milieu de dilution. CR Acad Sci Paris, série D $291: 649-652$

Billard R, Breton B (1970) Modifications ultrastructurales et cytochimiques des spermatozoïdes après dilution chez les poissons d'eau douce. Soc Fr Micros Electron, VIIe Congr Inter Micros Electron Grenoble, 632-637 
Burgos-Mario H, Fawcett Don W (1956) An electron microscope study of spermatid differentiation in the toad, Bufo arenarum (Hensel). J Biophys Biochem Cytol 2:223-240

Clark AW (1967) Some aspects of spermiogenesis in a lizard. Am J Anat 121:369-400

Elfvin LG (1968) An ultrastructural difference between the outer and inner membrane of the middle piece mitochondria in rat spermatozoa. J Ultrastruct Res 24:259-268

Fischer H, Hug O, Lippert W (1952) Elektronenmikroskopische Studien an Forellenspermatozoen und ihren Zellkernen. Chromosoma (Berl) 5:69-80

Furieri P (1962) Prime osservazioni al microscopio electronico sullo spermatozoo de Salmo trutta L. Bull Soc Ital Biol Sperm 38:1030-1032

Gibbons IR, Grimstone AV (1960) On flagellar structure in certain flagellates. J Biophys Biochem Cytol $7: 697-716$

Ginsburg AS (1963) Sperm-egg association and its relationship to the activation of the egg in salmonid fishes. J Embryol Exp Morphol 11:13-33

Horstmann E (1961) Elektronenmikroskopische Untersuchungen zur Spermiohistogenese beim Menschen. Z Zellforsch 54:68-89

Hug O, Lippert W, Fischer H (1953) Das elektronenoptische Bild der Salmonidenspermatozoen. Protoplasma 42:95-99

Idelman S (1967) Données récentes sur l'infrastructure du spermatozoïde. Ann Biol 6:113-189

Legendre M, Billard R (1980) Cryoconservation du sperme de truite Arc-en-ciel (Salmo gairdneri R.). Bull Fr Pisc 278:11-33

Mattei X (1969a) Contribution à l'étude de la spermiogenèse et des spermatozoïdes de poissons par les méthodes de la microscopie électronique. Thèse Fac Sci Montpellier, pp 148

Mattei X (1969b) Spermiogenèse comparée des poissons. Quaderno 137:57-69

Mattei X, Boisson Ch (1966) Le complexe centriolaire du spermatozoïde de Lebistes reticulatus. CR Acad Sci Paris, série D 262:2620-2622

Mattei X, Mattei C (1976) Ultrastructure du canal cytoplasmique des spermatozoides de téléostéens illustrée par l'étude de la spermiogenèse de Trichiurus lepturus. J Microscopie Biol Cell 25:249-258

MatteiX, Mattei C (1978a) La spermiogenèse d'un poisson téléostéen (Lepadogaster lepadogaster). Biol Cellulaire 32:267-274

MatteiX, Mattei C (1978b) La spermiogenèse d'un poisson téléostéen (Lepadogaster lepadogaster). Biol Cellulaire 32:257-266

Mattei X, Mattei C, Boisson Ch (1967) L'extrémité flagellaire du spermatozoïde de Lebistes reticulatus (Poecilidae). CR Soc Biol 161:884-887

Mattei C, Mattei X, Marchand B (1979) Réinvestigation de la structure des flagelles spermatiques. Les doublets $1,2,5$ et 6 . J Ultrastruc Res $69: 371-377$

Mattei C, Mattei X, Marchand B, Billard R (1981) Réinvestigation de la structure des flagelles spermatiques. Cas particulier des spermatozoïdes à mitochondrie annulaire. J Ultrastruc Res 74:307-312

Nicander L (1968) Gametogenesis and the ultrastructure of germ cells in vertebrates. VIe Congr Intern Reprod anim Insem artif Paris, INRA, 89-107

Nicander L, Bane A (1962) Fine structure of boar spermatozoa. Z Zellforsch 57:390-405

Porte A, Follénius E (1960) La spermiogenèse chez Lebistes reticulatus. Etude au microscope électronique. Bull Soc Zool France 85:82-88

Rotheli A, Roth H, Medem F (1950) Elektronenoptische Untersuchungen der Strukturveränderung agglutinierter Fischspermien. Exp Cell Res 1:115-126

Satir P (1965) Structure and formation in cilia and flagella. Protoplasmologia 3:1-51 